\title{
Plant community response to fuel break construction and goat grazing in a southern California shrubland
}

\author{
Ashley Grupenhoff ${ }^{*}$ (D) and Nicole Molinari ${ }^{2}$
}

\begin{abstract}
Background: Shrub-dominated ecosystems in California are widespread and provide invaluable ecosystem services to surrounding human-dominated communities. Yet shrublands, especially those at the wildland-urban interface, are at risk of degradation due to increasing wildfire frequency. Strategically placed fuel breaks are an important fuel management technique for reducing fire risk to neighboring communities and natural landscapes. Fuel breaks in shrub-dominated ecosystems are typically linear features where woody biomass is reduced, thereby providing fire suppression opportunities that limit fire spread. While fuel breaks are important for tactical response to fire, they can also affect the composition and structure of shrubland habitats. To understand the ecological changes resulting from fuel treatments in southern California chaparral, we measured vegetation change associated with fuel management techniques on a recently created fuel break established around the Lake Morena community on the Cleveland National Forest. The area was initially treated with cut and pile burning, then treated with herbicide, and 2 years later was subjected to short-term grazing by 1200 goats. The purpose of this study is to (1) evaluate the compositional and structural differences associated with fuel break creation and (2) quantify compositional shifts in herbaceous and woody vegetation caused by short-duration goat grazing as a method of fuel break maintenance.

Results: Plots on the fuel break and in untreated adjacent chaparral exhibited significantly different species assemblages. Total herbaceous cover (both native and non-native) was 92 times greater on the fuel break than in adjacent chaparral-dominated wildlands, and native shrub cover was 55.3 times greater in untreated adjacent chaparral than on the fuel break. Goats had a significant impact on reducing native and non-native herbaceous cover (87\% reduction in cover, 92\% reduction in height), but were ineffective at reducing the cover and height of most woody species such as Adenostoma fasciculatum, Eriogonum fasciculatum, Quercus berberidifolia, and Artemisia tridentata.

Conclusion: Initial fuel break creation was effective at reducing native woody cover and height, simultaneously giving rise to an abundance and diversity of native and non-native herbaceous species. Targeted goat grazing was successful at reducing herbaceous biomass but was ineffective at reducing woody biomass which is often one of the most important goals for fuel management in chaparral ecosystems. In areas where control of woody biomass is the primary objective, land managers should consider grazing duration and plant species composition when contemplating goats as a tool for fuel break maintenance.
\end{abstract}

Keywords: Chaparral, Disturbance ecology, Fire management, Fuel break, Fuel reduction treatments, Goat grazing, Non-native species

\footnotetext{
*Correspondence: agrupenhoff@ucdavis.edu

${ }^{1}$ Environmental Science and Policy, University of California Davis, Davis, USA

Full list of author information is available at the end of the article
}

\section{Springer Open}

(c) The Author(s). 2021 Open Access This article is licensed under a Creative Commons Attribution 4.0 International License, which permits use, sharing, adaptation, distribution and reproduction in any medium or format, as long as you give appropriate credit to the original author(s) and the source, provide a link to the Creative Commons licence, and indicate if changes were made. The images or other third party material in this article are included in the article's Creative Commons licence, unless indicated otherwise in a credit line to the material. If material is not included in the article's Creative Commons licence and your intended use is not permitted by statutory regulation or exceeds the permitted use, you will need to obtain permission directly from the copyright holder. To view a copy of this licence, visit http://creativecommons.org/licenses/by/4.0/. 


\section{Introduction}

California is a global biodiversity hotspot, largely covered by sage- and chaparral-dominated shrublands (Underwood et al. 2018). Yet, these ecosystems are threatened by an increase in wildfire frequency driven by increased urbanization of wildlands, warming temperatures, and invasion of non-native species (Abatzoglou and Williams 2016; Bruegger et al. 2016; Keeley and Fotheringham 2001). Wildfire activity has increased exponentially in many parts of California as a result of increased human ignitions and flammable vegetation, and a prolonged fire season. Increasing temperatures and reduced precipitation are likely to exacerbate the size and frequency of catastrophic fires by altering the amount and distribution of fuels and creating a shorter fire-return interval than historically present (Steel et al. 2015; Westerling and Bryant 2008). These altered fire regimes threaten biodiversity (Pausas and Keeley 2009) and increase fire risk to communities living in the wildland-urban interface (Syphard et al. 2007).

To mitigate these large destructive wildfires, fuel reduction treatments are implemented to reduce fire risk to neighboring communities and natural landscapes by changing fire behavior and limiting fire spread (Hardy 2005; Mell et al. 2010; Simard 1991). A primary form of fuel management in shrublands is the construction of strategic fuel breaks at the wildland-urban interface (WUI). The main goal of fuel break creation is to reduce woody biomass, consequently facilitating fire suppression activities that limit fire spread. Permanently converting a dense stand of chaparral to one of a lower fuel volume (e.g., cover, height) is often a multiple-step process that requires the initial removal of woody vegetation followed by periodic control of shrub species and reduction of herbaceous cover (Green 1977). Initial biomass removal may involve cut and pile burning (a form of vegetation removal where woody vegetation is manually removed above the base of the plant, placed in a pile, and burned), broadcast burning (a prescribed fire activity where fire is applied within a defined boundary for fuel hazard reduction), or mastication (a mechanical treatment that shreds understory vegetation onto the surface fuel layer). Herbicide use is one method for controlling regrowth after mature vegetation has been removed, but due to high costs and potential unintended consequences to other biota, there has been a need for alternative methods of controlling regrowth (Freemark \& Boutin 1995; Syphard et al. 2011; Wagner \& Nelson 2014).

Over the past few years, there is rising interest in controlling woody vegetation with domestic animals, such as goats, sheep, and horses. Some studies have investigated goat grazing as a way of reducing woody and herbaceous cover (Bartolome et al. 1998; Bashan \& BarMassada 2017; Gabay et al. 2011; Green and Newell
1982; Tsiouvaras et al. 1989); however, these studies have been mostly qualitative and have not quantified structural and compositional changes within chaparral-dominated landscapes in California. Additionally, few studies have examined the effectiveness of short-duration grazing in California chaparral. We evaluated the changes in response to fuel break creation and short-duration goat grazing by specifically addressing the questions:

(1) How do vegetation composition and structure change in a newly created fuel break?

(2) How does short-duration goat grazing affect the composition and structure of herbaceous and woody vegetation?

\section{Methods}

Study area

This study was conducted in a 47-hectare fuel break system established in eastern San Diego County around the Lake Morena community in the Cleveland National Forest (Fig. 1; $32.69^{\circ} \mathrm{N},-116.52{ }^{\circ} \mathrm{W}$ ). The study site experiences a Mediterranean climate, with subtropical high-pressure cells resulting in hot, dry summers and cool, wet winters. The chaparral plant communities at Lake Morena were dominated by shrub species, including Adenostoma fasciculatum Hook. \& Arn., Eriogonum fasciculatum Benth., Cercocarpus betuloides Nutt., and Quercus berberidifolia Liebm. Two tree species, Quercus agrifolia Née and Quercus engelmannii Greene, were also present though not common in the project area. A fuel break was initially created during fire suppression operations in the 1970s and was not disturbed again until October 2015 when the entire fuel break was treated with cut and pile burning. Trees were preserved in the fuel break during its creation. Herbicide was initially used to maintain the fuel break in May 2016, and 2 years later, 1200 goats were deployed at a rate of 10 goats per acre for 2 weeks in August 2018 within the fuel break to further reduce woody chaparral species. Initial vegetation surveys were conducted in July 2018, and vegetation plots were established in treated (cut and pile + herbicide, $N=16$ ) and untreated areas outside of the fuel break (untreated with no vegetation manipulation, $N=8$ ) (Fig. 1). Treated plots were subject to goat grazing in August 2018 and were re-sampled in October 2018 to capture the effects of grazing. Treatment plots that were surveyed before goat grazing are referred to as pre-grazing, and those after goat grazing are referred to as post-grazing.

\section{Experimental design}

The point line method (Heady et al. 1959) was used to inventory species composition, cover, and vegetation 


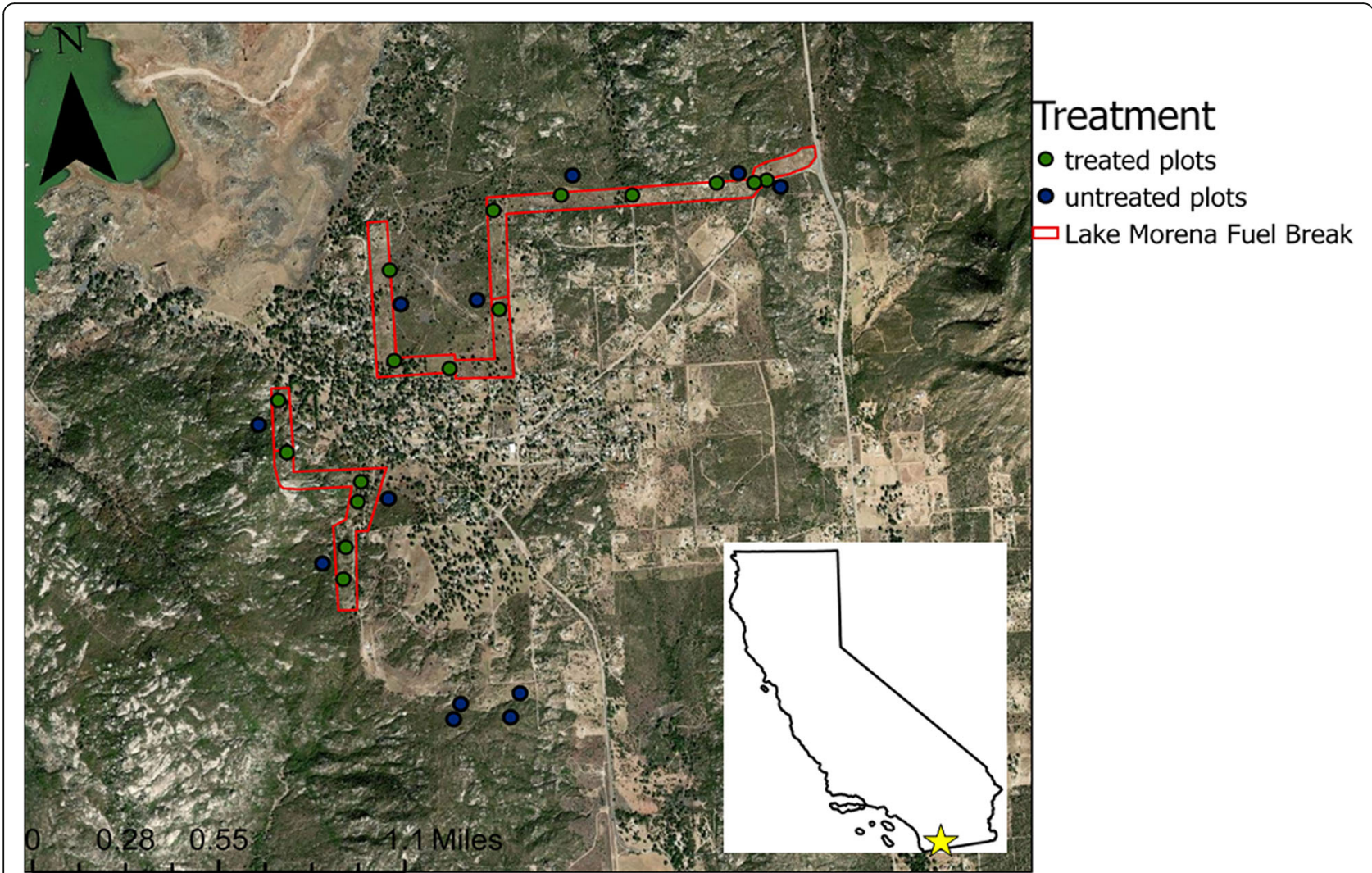

Fig. 1 Location of field plots indicated by green (fuel break) and blue (control) dots in relation to the Lake Morena fuel break (red polygon)

height in each plot. In total, twenty-four 30-m permanent line transects were established within the study site and one transect was measured per plot location. All species, both dead and alive, in addition to the height of the tallest individual were recorded at 100 points along each transect line. Plant species encountered along the transects were assigned to one of five lifeform categories (tree, live shrub, dead shrub, native grasses and forbs, and non-native grasses and forbs). Individual species cover, lifeform cover, species richness, and lifeform height were summarized for each transect and used to evaluate the effect of fuel break creation (comparison of untreated vs treated plots) and grazing (comparison of pre-grazing vs post-grazing plots) on shrubland composition and structure (Table 1).

\section{Statistical analysis}

Non-metric multidimensional scaling (NMDS) was used to visualize compositional differences between untreated and treated plots as a part of the 'vegan' package in $\mathrm{R}$ (Oksanen et al. 2011). The ordination uses rank-order correlation and Bray-Curtis dissimilarities, with the metaMDS function, to model the differences among treated and untreated plots based on species composition and abundance of all plant species. By presenting differences in species composition between samples, we can visualize differences between the fuel break and untreated adjacent chaparral.

Two sample $t$-tests were used to evaluate differences in lifeform cover, species richness, height, and ground cover between untreated $(N=8)$ and treated plots $(N=16)$. Paired $t$-tests were also used to evaluate the effects of goat grazing on lifeform cover, richness, and height by comparing pre-grazing $(N=16)$ to post-grazing plots $(N=16)$. Prior to analysis, data were checked for normality and homogeneity of variances. Data transformations and nonparametric statistical tests were adopted when the assumptions of the $t$-test were not fulfilled (details in Table 1).

All statistical analyses were done in Rstudio version 1.1.453 (Vienna, Austria) at $\alpha=0.05$, and we report means \pm 1 standard error (SE).

\section{Results}

\section{Compositional differences between treated and untreated areas}

Plots on the treated fuel break and untreated chaparral exhibit different species assemblages. The NMDS ordination of species composition resulted in a cluster of treated plots within the fuel break that contain more herbaceous species, while the untreated plots contain a 
Table 1 Summary of metrics inventoried. Lifeform categories include tree, live shrub, dead shrub, native herbaceous, and non-native herbaceous

\begin{tabular}{|c|c|c|c|c|c|c|}
\hline $\begin{array}{l}\text { Measurement } \\
\text { category }\end{array}$ & Measurement & Method & Reason & $\begin{array}{l}\text { Treatment } \\
\text { comparison }\end{array}$ & Statistical test & $\begin{array}{l}\text { Data } \\
\text { transformation }\end{array}$ \\
\hline Species cover & $\begin{array}{l}\text { Percent cover } \\
\text { of each } \\
\text { species (\%) }\end{array}$ & $\begin{array}{l}\text { The number of times an } \\
\text { individual of each species was } \\
\text { encountered at each of the } 100 \\
\text { points along the transect line }\end{array}$ & $\begin{array}{l}\text { Evaluate the } \\
\text { compositional } \\
\text { differences between } \\
\text { intact chaparral and } \\
\text { treated fuel break }\end{array}$ & $\begin{array}{l}\text { Untreated } \\
\text { vs treated }\end{array}$ & NMDS & \\
\hline \multirow[t]{2}{*}{ Lifeform cover } & \multirow[t]{2}{*}{$\begin{array}{l}\text { Percent cover } \\
\text { of each } \\
\text { lifeform } \\
\text { category (\%) }\end{array}$} & \multirow[t]{2}{*}{$\begin{array}{l}\text { The number of times a lifeform } \\
\text { category was encountered at } \\
\text { each of the } 100 \text { points along } \\
\text { the transect line }\end{array}$} & $\begin{array}{l}\text { Evaluate the difference } \\
\text { in lifeform cover } \\
\text { between intact } \\
\text { chaparral and treated } \\
\text { fuel break }\end{array}$ & $\begin{array}{l}\text { Untreated } \\
\text { vs treated }\end{array}$ & $\begin{array}{l}t \text {-test }=\text { all lifeform } \\
\text { categories, except } \\
\text { Wilcoxon rank-sum } \\
\text { for tree cover }\end{array}$ & $\begin{array}{l}\text { Square-root: shrub } \\
\text { cover, herb cover }\end{array}$ \\
\hline & & & $\begin{array}{l}\text { Evaluate the change in } \\
\text { lifeform cover due to } \\
\text { short-duration goat } \\
\text { grazing }\end{array}$ & $\begin{array}{l}\text { Pre-grazing } \\
\text { vs post- } \\
\text { grazing }\end{array}$ & $t$-test & $\begin{array}{l}\text { Square-root: herb } \\
\text { cover, tree cover }\end{array}$ \\
\hline \multirow[t]{2}{*}{$\begin{array}{l}\text { Species } \\
\text { richness }\end{array}$} & \multirow[t]{2}{*}{$\begin{array}{l}\text { Number of } \\
\text { species within } \\
\text { each lifeform } \\
\text { category } \\
\text { (count) }\end{array}$} & \multirow[t]{2}{*}{$\begin{array}{l}\text { Number of unique species } \\
\text { encountered along each of the } \\
100 \text { points along the transect } \\
\text { line }\end{array}$} & $\begin{array}{l}\text { Evaluate the difference } \\
\text { in species richness } \\
\text { between intact } \\
\text { chaparral and treated } \\
\text { fuel break }\end{array}$ & $\begin{array}{l}\text { Untreated } \\
\text { vs treated }\end{array}$ & $\begin{array}{l}t \text {-test }=\text { all lifeform } \\
\text { categories, except } \\
\text { Wilcoxon rank-sum } \\
\text { for tree richness }\end{array}$ & $\begin{array}{l}\text { Square-root: shrub } \\
\text { richness, herb } \\
\text { richness }\end{array}$ \\
\hline & & & $\begin{array}{l}\text { Evaluate the change in } \\
\text { species richness due to } \\
\text { short-duration goat } \\
\text { grazing }\end{array}$ & $\begin{array}{l}\text { Pre-grazing } \\
\text { vs post- } \\
\text { grazing }\end{array}$ & $\begin{array}{l}t \text {-test }=\text { all lifeform } \\
\text { categories, except } \\
\text { Wilcoxon rank-sum } \\
\text { for tree richness }\end{array}$ & $\begin{array}{l}\text { Square-root: dead } \\
\text { shrub richness, } \\
\text { herb richness; Sin: } \\
\text { live shrub richness }\end{array}$ \\
\hline \multirow[t]{2}{*}{ Lifeform height } & \multirow[t]{2}{*}{$\begin{array}{l}\text { Maximum } \\
\text { height for } \\
\text { each lifeform } \\
\text { category }(\mathrm{cm})\end{array}$} & \multirow[t]{2}{*}{$\begin{array}{l}\text { Average maximum height for } \\
\text { each lifeform category } \\
\text { encountered along each of the } \\
100 \text { points along the transect } \\
\text { line }\end{array}$} & $\begin{array}{l}\text { Evaluate the structural } \\
\text { differences between } \\
\text { intact chaparral and } \\
\text { treated fuel break }\end{array}$ & $\begin{array}{l}\text { Untreated } \\
\text { vs treated }\end{array}$ & $\begin{array}{l}t \text {-test }=\text { shrub } \\
\text { height; Wilcoxon } \\
\text { rank-sum = herb } \\
\text { height }\end{array}$ & \multirow[t]{2}{*}{$\begin{array}{l}\text { Square-root: shrub } \\
\text { height }\end{array}$} \\
\hline & & & $\begin{array}{l}\text { Evaluate the structural } \\
\text { differences caused by } \\
\text { short-duration goat } \\
\text { grazing }\end{array}$ & $\begin{array}{l}\text { Pre-grazing } \\
\text { vs post- } \\
\text { grazing }\end{array}$ & $\begin{array}{l}t \text {-test }=\text { shrub } \\
\text { height; Wilcoxon } \\
\text { rank-sum }=\text { herb } \\
\text { height }\end{array}$ & \\
\hline
\end{tabular}

greater abundance of shrub species (Fig. 2). Untreated plots that lacked fuel management, compared to treated plots, had 89.6 times $(t(17)=-9.56, P<0.001)$ and 55.3 times $(t(9)=-4.92, P<0.001)$ greater dead and live shrub cover, respectively (Fig. 3). Native herb cover was 88.1 times $(t(17)=6.52, P<0.001)$ and non-native herb cover was 96 times $(t(21)=5.21, P<0.001)$ greater in treated plots compared to the untreated plots (Fig. 3). Non-native grasses were more abundant than all the other herbaceous groups (native forbs, native grasses, and non-native forbs) in the treated plots with a significantly higher cover of Bromus tectorum L. and Bromus madritensis L. (Table 2). Treated and untreated plots did not differ in tree cover (Wilcoxon sign-ranked test, $P=0.92$ ). Total species richness at the $30-\mathrm{m}$ scale showed similar trends, with native herb richness 76.2 times $(t(14)=4.77, P<0.001)$ and nonnative richness 81.8 times $(t(22)=3.23, P<0.001)$ greater in the treated compared to untreated plots (Fig. 3). Live shrub and tree richness were uniform across treatment types, while dead shrub richness was higher in untreated plots.

Fuel break creation elicited structural differences across the landscape by changing lifeform height and ground cover. Herb height was 97 times greater (Wilcoxon signed-rank test, $P<0.001$ ) on treated plots than in control plots. Conversely, shrub height was 84.6 times greater $(t(8.9)=-7.89, P<0.001)$ and total fuel height was 31.5 times greater (Wilcoxon signed-rank test, $P=0.045$ ) on plots that lacked fuel management (Fig. 4). There was a trend for bare ground cover to be greater on treated plots $(t(22)=1.94, P=0.065)$ with untreated plots having substantially more wood and litter $(t(10.8)=-3.99, P=0.002 ; t(22)=-2.62, P=0.016$; respectively) than treated plots (Additional File 1).

\section{Compositional and structural differences before and after goat grazing}

To determine if goats were effective at reducing herbaceous and woody vegetation across the fuel break, we repeated our analysis of vegetation cover, richness, and height differences with a paired $t$-test on treatment areas inside the fuel break before and after grazing. We found an $87 \%$ reduction in herb cover due to grazing $(t(15)=$ 9.74, $P<0.001$; Figs. 5 and 7). Grazing led to a decrease in native herb cover from $17.88 \pm 2.6 \%$ to $2.38 \pm 1.0 \%$ $(t(15)=11.07, P<0.001)$ and a decrease in non-native 


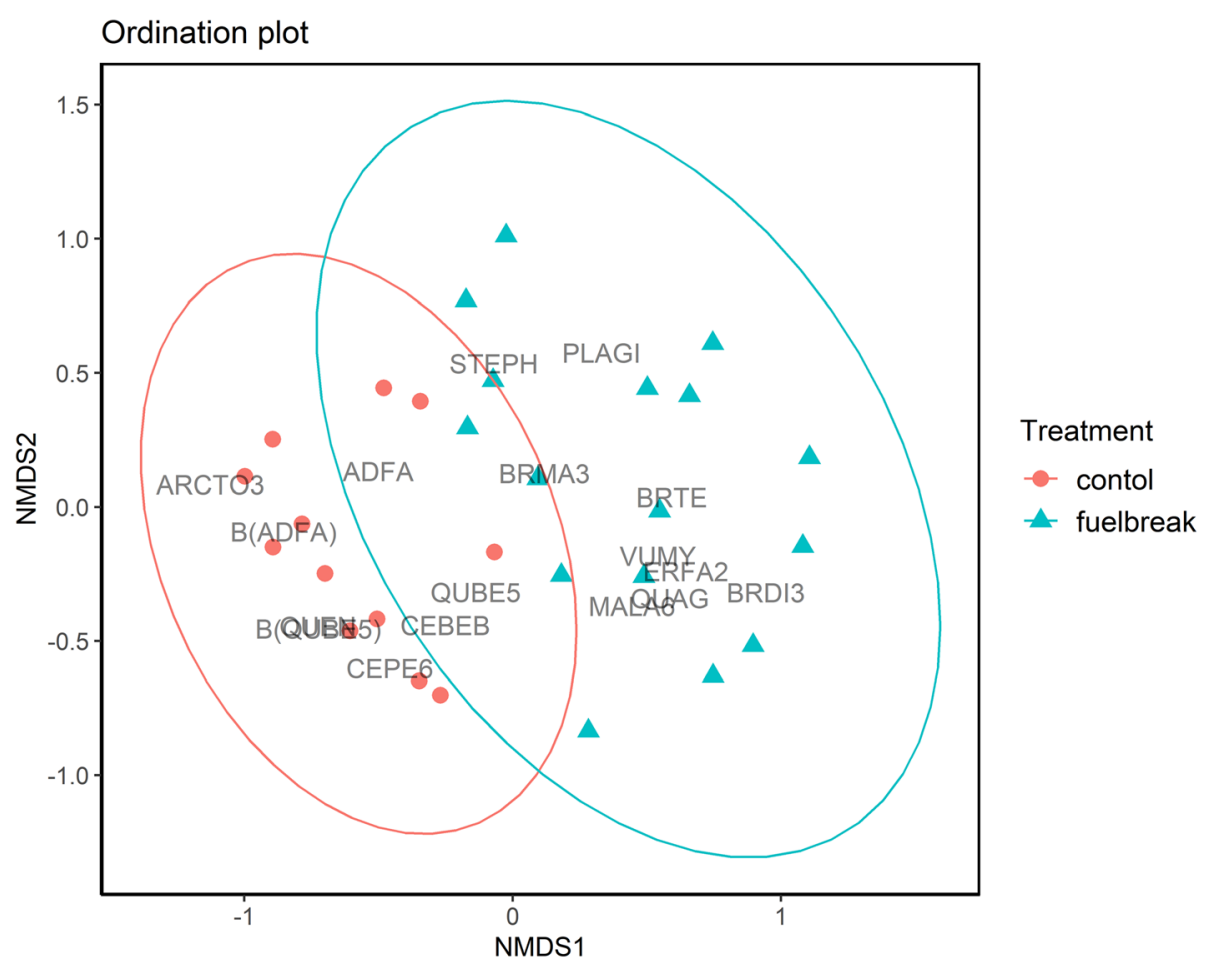

Fig. 2 Non-metric multidimensional scaling plot (NMDS) of Bray-Curtis dissimilarity matrix based on species composition from survey plots. Each point represents a survey plot, and the compositional dissimilarity between plots is indicated by the spread along the two NMDS axes. Undisturbed chaparral plots (control, pink circles) are clustered more closely together than fuel break plots (blue triangles), indicating that they are more similar in species composition. Control plots have an abundance of native woody vegetation, whereas fuel break plots are largely comprised of native and non-native herbs. Labeling priority was given to more abundant and frequent species. Species codes: ADFA Adenostoma fasciculatum, ARCTO3 Arctostaphylos, BRDI3 Bromus diandrus, BRMA3 Bromus madritensis, BRTE Bromus tectorum, CEBEB Cercocarpus betuloides, CEPE Ceanothus perplexans, ERFA2 Eriogonum fasciculatum, MALA6 Malosma laurina, PLAGI Plagiobothrns, QUAG Quercus agrifolia, QUBE5 Quercus berberidifolia, QUEN Quercus engelmannii, STEPH Stephanomeria, VUMY Vulpia myuros. B(species) represents a dead branch of a live individual at the sampling point. Final stress of three-dimensional solution $=0.191$ after 20 iterations

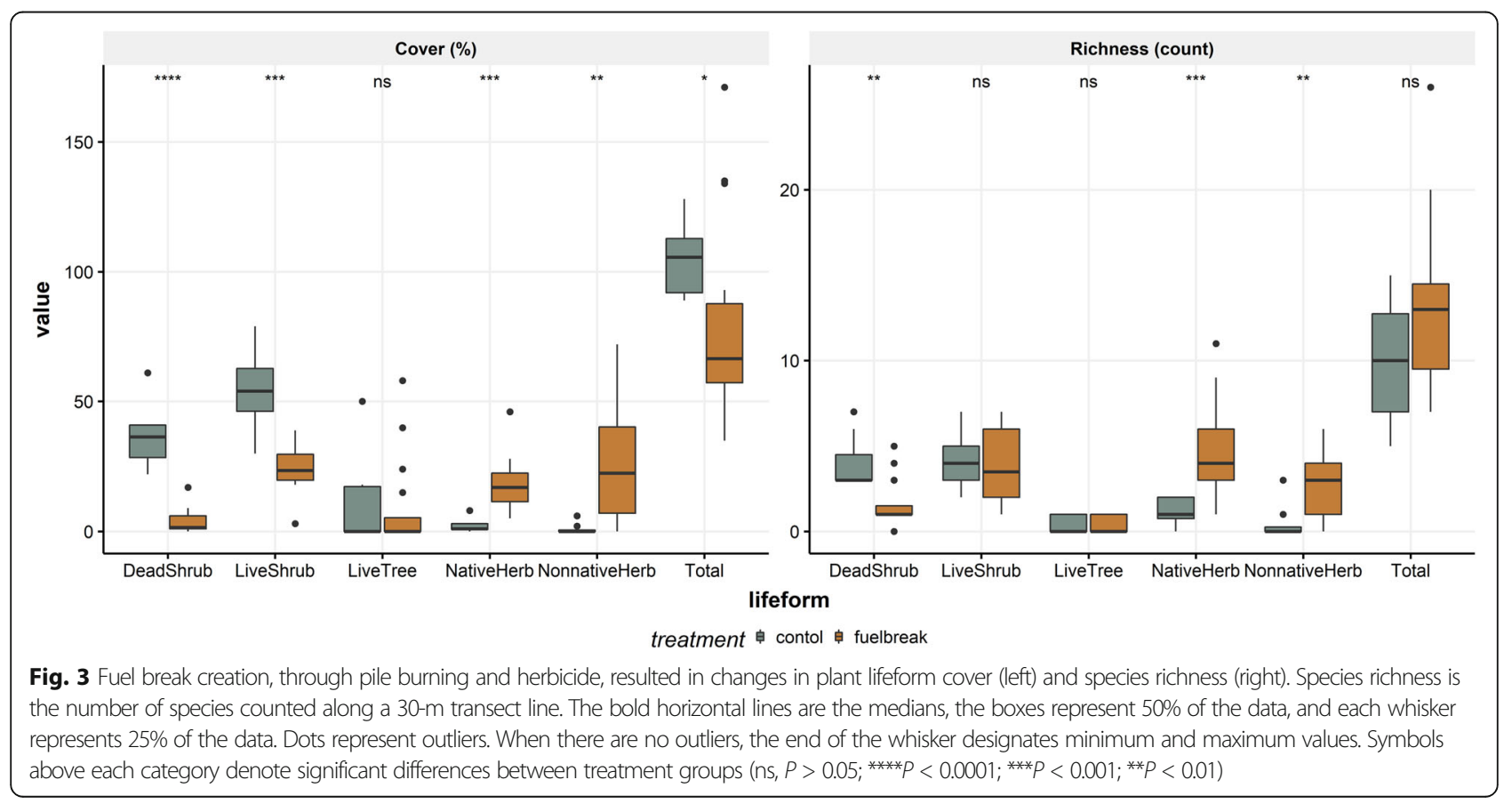


Table 2 List of most abundant non-native herbaceous species throughout the study area. For each treatment, the average plant cover (\%) is calculated across each 30-m transect

\begin{tabular}{|c|c|c|c|c|}
\hline Non-native herbaceous species & Cal-IPC rating & Pre-grazing cover & Post-grazing cover & Control (untreated) cover \\
\hline Bromus diandrus Roth & Moderate & $6.38 \pm 3.5$ & $0.19 \pm 0.1$ & $0.00 \pm 0.0$ \\
\hline Bromus madritensis L. & High & $10.13 \pm 2.8$ & $0.00 \pm 0.0$ & $0.63 \pm 0.42$ \\
\hline Bromus tectorum L. & High & $7.44 \pm 2.9$ & $2.63 \pm 0.9$ & $0.25 \pm 0.3$ \\
\hline Festuca myuros L. & Moderate & $2.38 \pm 1.2$ & $0.00 \pm 0.0$ & $0.13 \pm 0.4$ \\
\hline Brassica tournefortii Gouan & High & $0.50 \pm 0.4$ & $0.00 \pm 0.0$ & $0.00 \pm 0.0$ \\
\hline Avena sp. L. & & $0.50 \pm 0.3$ & $0.00 \pm 0.0$ & $0.00 \pm 0.0$ \\
\hline
\end{tabular}

herb cover from $25.25 \pm 5.2 \%$ to $3.19 \pm 0.9 \%(t(15)=$ 14.30, $P<0.001)$. Generally, goats had a high preference for Bromus madritensis L. (100\% reduction, $t(15)=5.28$, $P<0.001)$ and Bromus diandrus Roth (97\% reduction, Wilcoxon rank-sum, $P=0.281$ ) while Bromus tectorum L. (60\% reduction, $(t(15)=1.31, P=0.213)$ was the only herbaceous species to persist with $>1 \%$ cover following goat grazing (Table 2). There was no significant decline in shrub cover $(t(15)=1.70, P=0.114)$ or tree cover $(t(15)=0.68, P=0.509)$ due to grazing, but generally, goats had a low preference for Adenostoma fasciculatum, Eriogonum fasciculatum, and Ericameria species while mostly targeting Cercocarpus betuloides and Eriophyllum confertiflorum (Table 3; Fig. 8).

Grazing elicited similar trends in species richness at the $30-\mathrm{m}$ scale (Fig. 5). We found a $77.5 \%$ reduction in herb richness, with grazing decreasing native herb richness from $4.75 \pm 0.6$ to $1.00 \pm 0.3(t(15)=7.32, P<$ $0.001)$ and a decrease in non-native herb richness from $2.75 \pm 0.5$ to $0.69 \pm 0.2(t(15)=-3.08, P<0.001)$. Grazing did not cause a significant difference in live shrub $(t(15)=0.17, P=0.869)$, dead shrub $(t(15)=-0.08, P=$ 0.938 ), or tree (Wilcoxon signed-rank test, $P=1.00$ ) richness.

Grazing induced changes in vegetation structure across the landscape by changing lifeform height. There was a significant decrease in herb height from $17.1 \pm 2.2$ $\mathrm{cm}$ pre-grazing to $15.3 \pm 2.6 \mathrm{~cm}$ post-grazing (Wilcoxon sign-ranked test, $P<0.001$ ), but there was no significant difference in shrub height $(t(15)=0.075, p=0.491)$ (Fig. 6). While we did not measure ground to the base of the crown height for trees, we observed that goats were effective at increasing this distance through the liming and consumption of the lower branches (Fig. 7).

\section{Discussion}

This study demonstrates the complexity of fuel break creation and maintenance that involve a stepwise process in vegetation change. The removal of woody vegetation to create a fuel break has significant effects on vegetation cover and species richness, as we expected. We found compositional differences driven by a

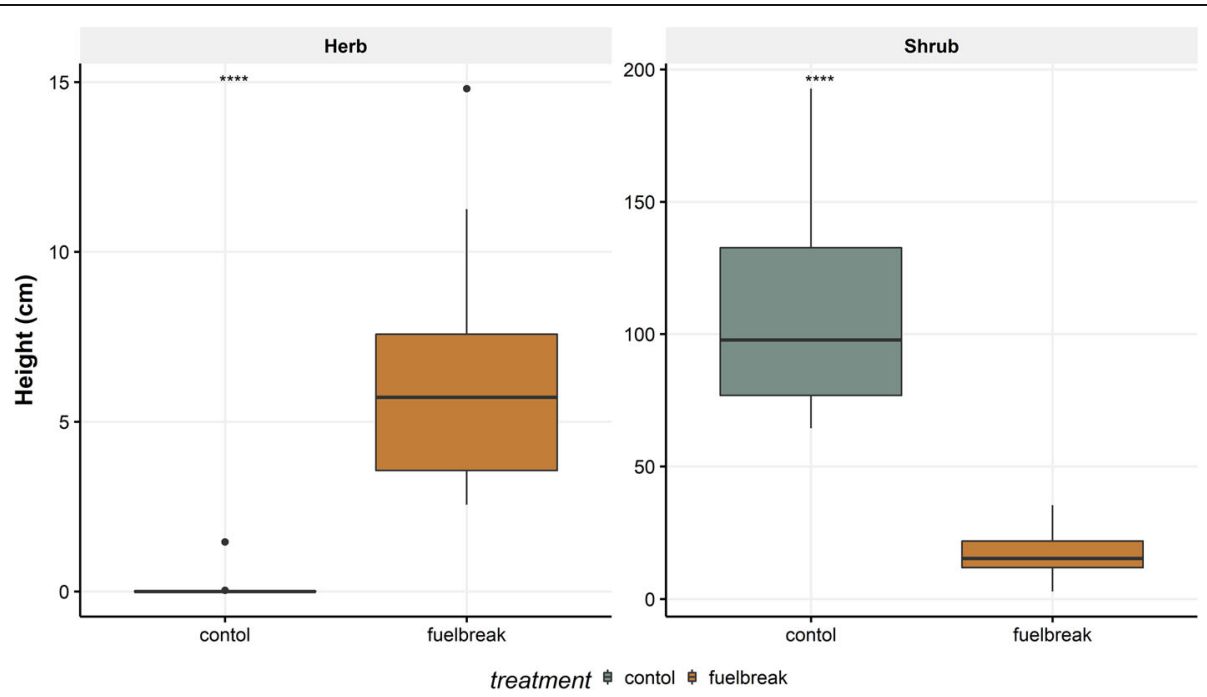

Fig. 4 Fuel break creation, through pile burning and herbicide, resulted in changes to mean herbaceous height (left) and shrub height (right). The bold horizontal lines are the medians, the boxes represent $50 \%$ of the data, and each whisker represents 25\% of the data. Dots represent outliers. When there are no outliers, the end of the whisker designates minimum and maximum values. Symbols above each category denote significant differences between treatment groups $(* * * *<0.0001)$ 


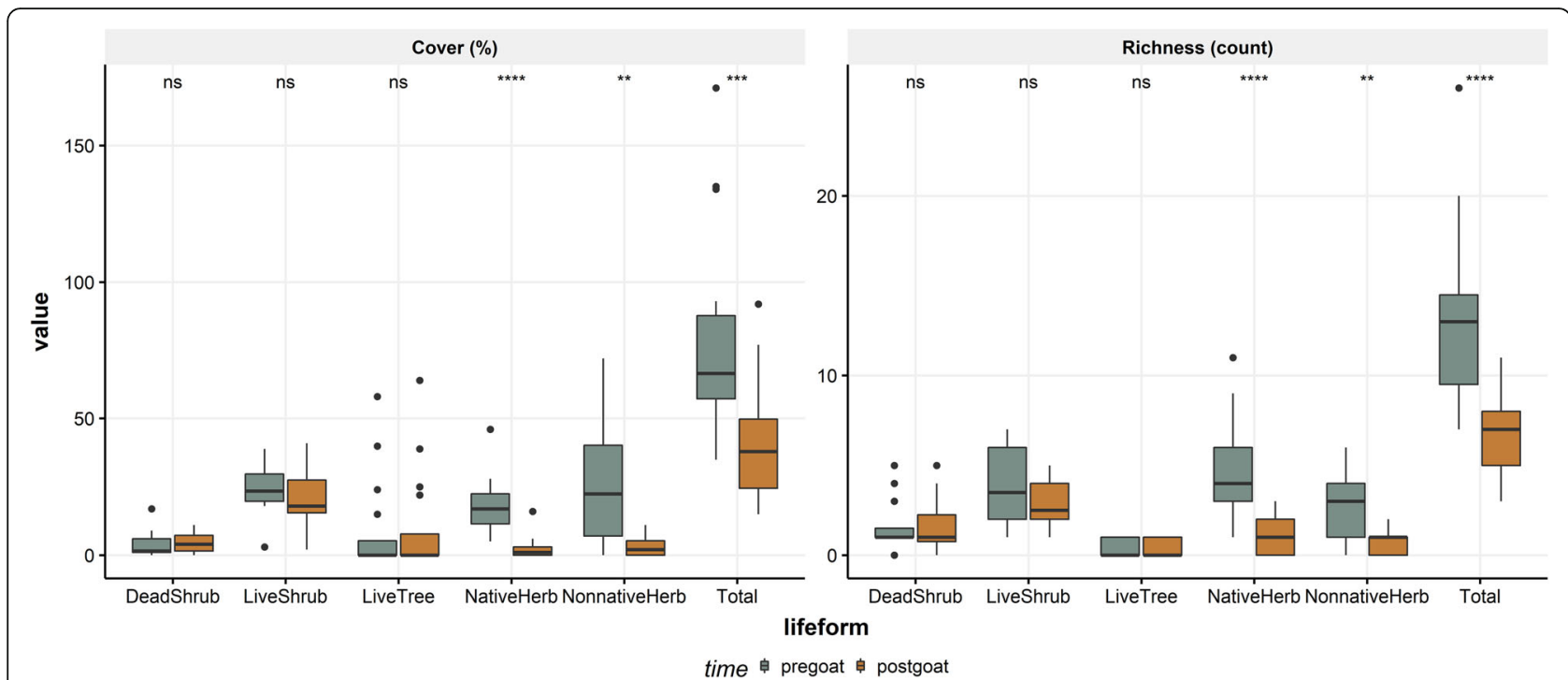

Fig. 5 Goat grazing resulted in changes in plant lifeform cover (left) and species richness (right). Species richness is the number of species counted along a 30-m transect line. The bold horizontal lines are the medians, the boxes represent $50 \%$ of the data, and each whisker represents $25 \%$ of the data. Dots represent outliers. When there are no outliers, the end of the whisker designates minimum and maximum values. Symbols above each category denote significant differences between treatment groups (ns, $P>0.05 ;{ }^{* * *} P<0.0001 ;{ }^{* * *} P<0.001 ;{ }^{* *} P<0.01$ )

decrease in the abundance of shrubs and a higher abundance and diversity of herbaceous species inside of the fuel break compared to non-disturbed areas. Chaparral shrublands are known for exhibiting unparalleled temporal diversity with substantial herbaceous richness (e.g., fire followers) being expressed following wildfire (Keeley et al. 2005). Herbaceous species can be triggered by various processes associated with shrub removal, such as heat, smoke, and chemical byproducts of the fire (Keeley and Fotheringham 2001). The process of fuel reduction may mimic some of the post-fire processes by increasing temperature at the soil surface or via scarification caused by ground-disturbing fuel reduction activities. Shrub removal may also lead to light-associated cues for germination (Le Maitre and Brown 1992, Stone 1951). It is important to note that this study was conducted on a relatively new fuel break and the difference in richness and cover for older fuel breaks is not likely to track our findings.

The fuel break complex at Lake Morena was recently opened in 2015, and we propose that fuel break creation promotes an increase in native and non-native species initially, but repeated disturbances may lead to degradation that includes an increase in non-native annual species at the expense of native species. The dominance of non-native annuals, especially grasses, may be reinforced in frequently disturbed areas through higher germination rates, competitive superiority, and accumulation of a persistent thatch layer (Molinari and D'Antonio 2020; Parendes and Jones 2000; Reynolds et al. 2001). Merriam et al. (2006) found that fuel break construction was strongly associated with moderately high non-native abundance and showed that over time, with repeat disturbance, non-natives can displace native species and become increasingly dominant. An increase in non-native

Table 3 List of most abundant shrub species throughout the study area. For each treatment, the average plant cover (\%) is calculated across each 30-m transect

\begin{tabular}{llll}
\hline Shrub species & Pre-grazing cover & Post-grazing cover & Control (untreated) cover \\
\hline Adenostoma fasciculatum Hook. \& Arn. & $9.63 \pm 2.3$ & $9.25 \pm 2.2$ & $31.50 \pm 5.12$ \\
Eriogonum fasciculatum Benth. & $3.38 \pm 1.5$ & $2.81 \pm 1.1$ & $1.00 \pm 1.0$ \\
Quercus berberidifolia Liebm. & $2.38 \pm 1.4$ & $2.5 \pm 1.6$ & $4.25 \pm 2.28$ \\
Cercocarpus betuloides Nutt. & $1.50 \pm 0.9$ & $0.88 \pm 0.5$ & $5.63 \pm 2.39$ \\
Rhus aromatica Aiton & $1.31 \pm 0.9$ & $0.94 \pm 0.6$ & $1.00 \pm 0.65$ \\
Artemisia tridentata Nutt. & $1.00 \pm 0.6$ & $1.00 \pm 0.6$ & $0.00 \pm 0.0$ \\
Eriophyllum confertiflorum (DC.) A. Gray & $1.13 \pm 0.4$ & $0.00 \pm 0.0$ & $0.13 \pm 0.1$ \\
\hline
\end{tabular}




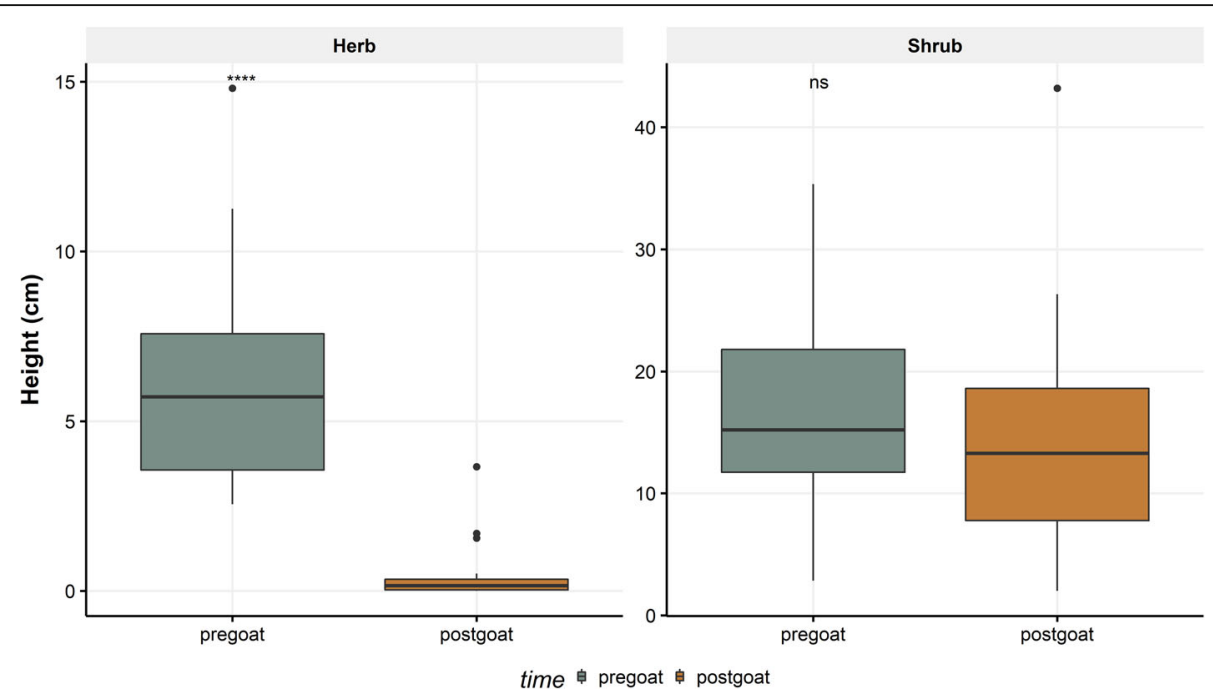

Fig. 6 Goat grazing resulted in changes to mean herbaceous height (left) and shrub height (right). The bold horizontal lines are the medians, the boxes represent $50 \%$ of the data, and each whisker represents $25 \%$ of the data. Dots represent outliers. When there are no outliers, the end of the whisker designates minimum and maximum values. Symbols above each category denote significant differences between treatment groups (ns, $\left.P>0.05 ;{ }^{* * *} P<0.0001\right)$

species on the landscape is detrimental as it not only changes soil nutrient cycling that is unfavorable to native species (Evans 2001), but it alters fuel characteristics such that fires become more frequent (D'Antonio and Vitousek 1992; Keeley 2001). More specifically, nonnative grasses are associated with increased fuel ignitability, fine-fuel loads, and fuel continuity, thus increasing fire occurrence and frequency at the regional scale (Fusco et al. 2019).

While the Lake Morena fuel break complex is currently exhibiting signs of increased herbaceous diversity, with repeated maintenance, we suspect species diversity will decline and non-native species will become the dominant vegetation type in this area. Alternatively, if this fuel break is not maintained and lacks future disturbance, herbaceous richness and cover are likely to decline due to the regrowth of shrubs and the exclusion of many non-native and native annuals that were able to persist immediately after disturbance.

Controlling woody regrowth is vital to the functioning of fuel breaks for fire suppression operations. Therefore, understanding the effectiveness of alternative maintenance methods, such as goat grazing, is imperative. We found that short-duration targeted grazing was ineffective at reducing the height and cover of most woody vegetation, apart from Eriophyllum confertiflorum and Cercocarpus betuloides (Fig. 8). During a 2-week period, goats showed high selectivity when browsing shrubs and had a low preference for many of the dominant shrub species at Lake Morena. However, longer-term grazing can have a

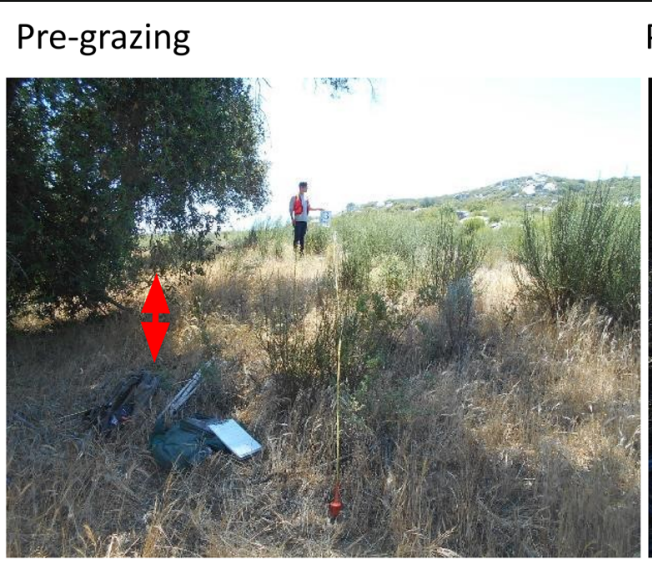

\section{Post-grazing}

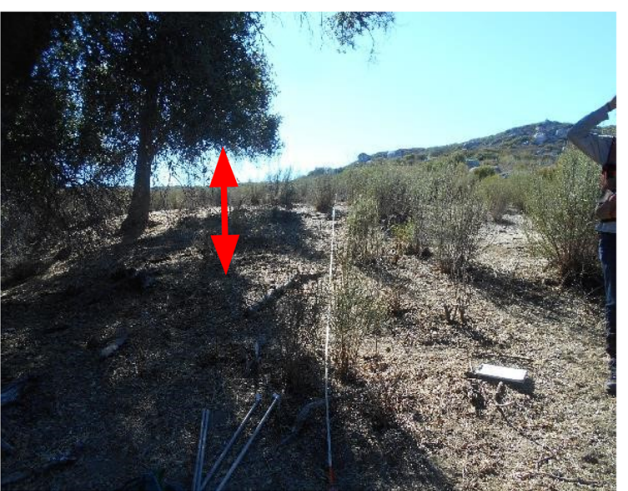

Fig. 7 Goat grazing was effective at reducing the distance from ground to base of crown height on Quercus agrifolia. Note the significant reduction in herbaceous cover due to grazing. Photos taken by authors 

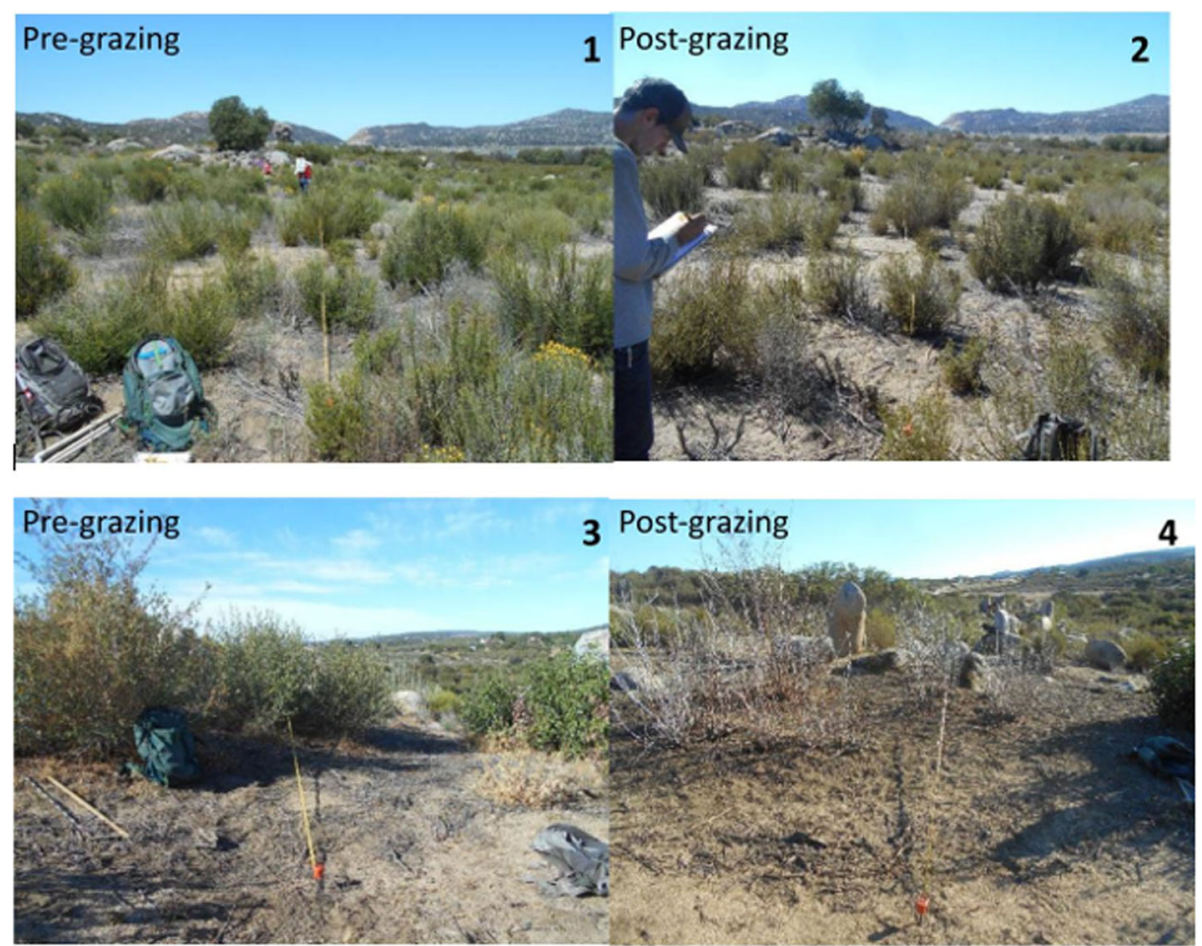

Fig. 8 Overall, there was no significant decline in shrub cover due to goat grazing. Generally, goats had a low preference for Adenostoma fasciculatum, Eriogonum fasciculatum, and Ericameria species (1 1 and $\mathbf{2}$ ) while mostly targeting Cercocarpus betuloides and Eriophyllum confertiflorum (3 and $\mathbf{4})$. Photos taken by authors

different outcome on woody vegetation. Many studies have shown that grazing over a longer time and intensity can successfully reduce woody vegetation cover and regeneration (Bashan \& Bar-Massada 2017; Gabay et al. 2011). If the main goal of using goats is to reduce woody biomass, then the duration of grazing should be considered when determining if it is an economically feasible alternative to other methods of controlling regrowth.

Goat grazing strongly reduced both native and nonnative herbaceous cover and height, which may be desirable in areas where flashy fuels and ignition risk are a concern. It is important to note that goats also removed most of the non-natives on the landscape ( $87 \%$ reduction) but tended to leave a higher cover of Bromus tectorum L. Of the $3.2 \%$ of the non-native herbaceous cover remaining after grazing, 3.0\% was comprised of $B$. tectorum. Goats tended to avoid this species while eliminating other dominant non-native species, such as Bromus madritensis L. B. tectorum is palatable for 6 to 8 weeks in the spring; however, when grazed later in the summer, the long, straight awns can damage the eyes and mouth of grazers (Mosley et al. 1999). Although there is only $3.0 \%$ cover of B. tectorum cover at Lake Morena, this small amount may be sufficient for prolonged persistence which can displace native species, alter fire regimes, and modify hydrological properties
(Arkle et al. 2014; Blank and Morgan 2013; Monaco et al. 2016). Land managers interested in using goats to control undesirable non-native species should take into account the phenology and palatability of the target non-native species.

Although goats successfully reduced herbaceous biomass, the reduction of woody biomass is often one of the most important goals for fuel management in chaparral ecosystems. Goats will eat a wide variety of species compared to most livestock but can be selective in targeting plants that are in a favorable growth stage, depending on the duration of grazing (Bashan \& BarMassada 2017; Green and Newell 1982). Goats behave as browsers in Mediterranean landscapes (Bartolome et al. 1998) and have been shown to successfully reduce woody and herbaceous cover (Gabay et al. 2011). Intense goat grazing applied during several periods throughout the growing season not only prevents woody regeneration but has been shown to significantly decrease woody cover (Bashan \& Bar-Massada 2017). The Lake Morena study examines short-duration goat grazing and shows that although goats were successful at reducing herbaceous cover, longer-duration grazing is likely necessary for woody biomass reduction. Due to the selectivity of goats in targeting woody plants, land managers should consider the seasonality, stage of regrowth, and 
species composition when deciding whether goats are an appropriate tool for fuel break maintenance (Bartolome et al. 1998).

\section{Conclusions}

With warming temperatures and continued development into the wildland-urban interface, chaparral-dominated shrublands are threatened by an increase in wildfire frequency. As pressure mounts to develop and maintain fuel breaks on the landscape, it becomes increasingly important to understand the effectiveness and consequences of various fuel reduction techniques on shrubland habitats. Initial fuel break creation through cut and pile and herbicide application at Lake Morena was effective at reducing woody biomass and height, while simultaneously giving rise to an abundance and diversity of native and non-native herbaceous species. While this may superficially appear to be a win-win for fuel management and ecology, it is important to note that with repeated maintenance, fuel breaks are likely to become increasingly dominated by undesirable non-native species. Goat grazing was ineffective at reducing height and cover of woody vegetation but was successful in reducing both native and non-native herbaceous cover and height, which may be desirable in areas where flashy fuels and ignition risk are high. However, in areas where control of woody biomass is the primary goal, land managers should consider the seasonality, duration, and plant species composition when contemplating goats as a tool for fuel break maintenance.

\section{Abbreviations}

WUI: Wildland-urban interface

\section{Supplementary Information}

The online version contains supplementary material available at https://doi. org/10.1186/s42408-021-00114-3.

Additional file 1. Details for evaluating changes in ground cover due to goat grazing.

\section{Acknowledgements}

We thank our cooperators from the Cleveland National Forest: Jamie Miller, Stephen Fillmore, Andrew Weinhart, and Rick Marinelli. We also thank Ryan Fass, Jack Betz, and Kalina Stork for field assistance. We are grateful to an anonymous reviewer for their comments.

\section{Authors' contributions}

AG analyzed and interpreted all data regarding compositional and structural changes to vegetation caused by fuel break creation and goat grazing. NM created the sampling design and was a major contributor in data interpretation and writing the manuscript. All authors read and approved the final manuscript.

\section{Funding}

Not applicable

\section{Availability of data and materials}

The datasets used and analyzed during the current study are available from the corresponding author upon reasonable request.

\section{Declarations}

Ethics approval and consent to participate

Not applicable

\section{Consent for publication}

Not applicable

\section{Competing interests}

The authors declare that they have no competing interests.

\section{Author details}

${ }^{1}$ Environmental Science and Policy, University of California Davis, Davis, USA. ${ }^{2}$ USDA Forest Service, Southern California Province, 1980 Old Mission Dr, Solvang, CA 93463, USA.

Received: 22 January 2021 Accepted: 12 July 2021

Published online: 02 November 2021

\section{References}

Abatzoglou, J.T., and A.P. Williams. 2016. Impact of anthropogenic climate change on wildfire across western US forests. Proc Natl Acad Sci 113 (42): 11770-11775. https://doi.org/10.1073/PNAS.1607171113.

Arkle, R.S., D.S. Pilliod, S.E. Hanser, M.L. Brooks, J.C. Chambers, J.B. Grace, K.C. Knutson, D.A. Pyke, J.L. Welty, and T.A. Wirth. 2014. Quantifying restoration effectiveness using multi-scale habitat models: implications for sage-grouse in the Great Basin. Ecosphere 5: 31.

Bartolomé, J., J. Franch, J. Plaixats, and N.G. Seligman. 1998. Diet selection by sheep and goats on Mediterranean heath-woodland range. J Range Manag 51 (4): 383-391. https://doi.org/10.2307/4003322.

Bashan, D., and A. Bar-Massada. 2017. Regeneration dynamics of woody vegetation in a Mediterranean landscape under different disturbance-based management treatments. Appl Veg Sci 20 (1): 106-114. https://doi.org/1 $0.1111 /$ avsc. 12274 .

Blank, R.R., and T. Morgan. 2013. Soil engineering facilitates downy brome (Bromus tectorum) growth - a case study. Invasive Plant Sci Manag 6 (3): 391-400. https://doi.org/10.1614/IPSM-D-12-00086.1.

Bruegger, R.A., L.A. Varelas, L.D. Howery, L.A. Torell, M.B. Stephenson, and D.W. Bailey. 2016. Targeted grazing in southern Arizona: using cattle to reduce fine fuel loads. Rangel Ecol Manag 69 (1): 43-51. https://doi.org/10.1016/j.ra ma.2015.10.011.

D'Antonio, C.M., and P.M. Vitousek. 1992. Biological invasions by non-native grasses, the grass/fire cycle, and global change. Annu Rev Ecol Evol Syst 23 (1): 63-87. https://doi.org/10.1146/annurev.es.23.110192.000431.

Evans, R.D., R. Rimer, L. Sperry, and J. Belnap. 2001. Non-native plant invasion alters nitrogen dynamics in an arid grassland. Ecol Appl 11 (5): 1301-1310. https://doi.org/10.1890/1051-0761(2001)011[1301:EPIAND]2.0.CO;2.

Freemark, K., and C. Boutin. 1995. Impacts of agricultural herbicide use on terrestrial wild life in temperate landscapes: a review with special reference to North America. Agri Ecosyst Environ 52 (2-3): 67-91. https://doi.org/10.1016/01 67-8809(94)00534-L.

Fusco, E.J., J.T. Finn, J.K. Balch, R.C. Nagy, and B.A. Bradley. 2019. Invasive grasses increase fire occurrence and frequency across US ecoregions. Proc Natl Acad Sci 116 (47): 23594-23599. https://doi.org/10.1073/pnas.1908253116.

Gabay, O., A. Perevolotsky, A. Bar-Massada, Y. Carmel, and M. Shachak. 2011. Differential effects of goat browsing on herbaceous plant community in a two-phase mosaic. Plant Ecol 212 (10): 1643-1653. https://doi.org/10.1007/ s11258-011-9937-8.

Green, L. 1977. Fuelbreaks and other fuel modification for wildland fire control. USDA For Serv Agric Handb 499: 1-84.

Green, L.R., and L.A. Newell. 1982. Using goats to control brush regrowth on fuel breaks. USDA Gen Tech Rep PSW-59: 1-13.

Hardy, C.C. 2005. Wildland fire hazard and risk: problems, definitions, and context. For Ecol Manage 211 (1-2): 73-82. https://doi.org/10.1016/j.foreco.2005.01.029.

Heady, H.F., R.P. Gibbens, and R.W. Powell. 1959. A comparison of the charting, line intercept, and line point methods of sampling shrub types of vegetation. J Range Manag 12 (4): 180-188. https://doi.org/10.2307/3894848.

Keeley, J.E. 2001. Fire and invasive species in Mediterranean-climate ecosystems of California. Fire conference (2000): the first national congress on fire ecology, prevention, and management. San Diego, California, USA.: Tall Timbers Research Station. 
Keeley, J.E., and C.J. Fotheringham. 2001. Historic fire regime in southern California shrublands. Conserv Biol 15 (6): 1536-1548. https://doi.org/10.1046/ j.1523-1739.2001.00097.x.

Keeley, J.E., C.J. Fotheringham, and M. Baer-Keeley. 2005. Factors affecting plant diversity during post-fire recovery and succession of mediterranean-climate shrublands in California, USA. Divers Distrib 11 (6): 525-537. https://doi.org/1 0.1111/j.1366-9516.2005.00200.x.

Le Maitre, D.C., and P.J. Brown. 1992. Life cycles and fire-stimulated flowering in geophytes. In Fire in South African Mountain Fynbos, ed. B.W. van Wilgen, D. M. Richardson, F.J. Kruger, and J.H. van Hensbergen, 145-160. New York: Springer-Verlag. https://doi.org/10.1007/978-3-642-76174-4_8.

Mell, W., S. Manzello, A. Maranghides, et al. 2010. The wildland - urban interface fire problem - current approaches and research needs. Int I Wildl Fire 19 (2): 238-251. https://doi.org/10.1071/WF07131.

Merriam KE, Keeley JE, Beyers JL (2006) Fuel breaks affect non-native species abundance in Californian plant communities. Ecol Appl 16:515-527. https:// doi.org/10.1890/1051-0761(2006)016[0515:FBANSA]2.0.CO;2, 2.

Molinari, N.A., and C.M. D'Antonio. 2020. Where have all the wildflowers gone? The role of exotic grass thatch. Biol. Invasions 22 (3): 957-968. https://doi.org/1 0.1007/s10530-019-02135-1.

Monaco, T.A., J.M. Mangold, B.A. Mealor, R.D. Mealor, and C.S. Brown. 2016. Downy brome control and impacts on perennial grass abundance: a systematic review spanning 64 years. Rangel Ecol Manag. 70: 396-404.

Mosley, J.C., S.C. Bunting, and M.E. Manoukian. 1999. Cheatgrass. In Biology and Management of Noxious Rangeland Weeds, ed. R.L. Sheley and J.K. Petroff, 175-188. Corvallis: Ore. State Univ. Press.

Oksanen J, Blanchet FG, Legendre P, O'Hara RB, Simpson GL, Peter Solymos M, Stevens HH, Wagner H (2011) Vegan: Community Ecology Package. R package version 1.17-4. http://vegan. r-forge.r-project.org/.

Parendes, L.A., and J.A. Jones. 2000. Role of light availability and dispersal in exotic plant invasion along roads and streams in the $\mathrm{H}$. J. Andrews Experimental Forest. Oregon. Conserv. Biol. 14 (1): 64-75. https://doi.org/10.1 046/j.1523-1739.2000.99089.x.

Pausas, J.G., and J.E. Keeley. 2009. A burning story: the role of fire in the history of life. Bioscience 59 (7): 593-601. https://doi.org/10.1525/bio.2009.59.7.10.

Reynolds, S.A., J.D. Corbin, and C.M. D'Antonio. 2001. The effects of litter and temperature on the germination of native and non-native grasses in a coastal California grassland. Madrono 48: 230-235.

Simard, A.J. 1991. Fire severity, changing scales, and how things hang together. Int J Wildl Fire 1: 23-34 https://doi.org/10.1071/WF9910023, 1.

Steel, Z.L., H.D. Safford, and J.H. Viers. 2015. The fire frequency-severity relationship and the legacy of fire suppression in California forests. Ecosphere 6: 1-8 https://doi.org/10.1890/es14-00224.1, 1 .

Stone, E.C. 1951. The stimulative effect of fire on the flowering of the golden brodiaea (Brodiaea ixiodes Wats. var. lugens Jeps.). Ecology 32 (3): 534-537. https://doi.org/10.2307/1931729.

Syphard, A.D., V.C. Radeloff, J.E. Keeley, T.J. Hawbaker, M.K. Clayton, S.I. Stewart, and R.B. Hammer. 2007. Human influence on California fire regimes. Ecol Appl 17 (5): 1388-1402. https://doi.org/10.1890/06-1128.1.

Syphard, A.D., J.E. Keeley, and T.J. Brennan. 2011. Comparing the role of fuel breaks across southern California national forests. Forest Ecol Manag 261 (11): 2038-2048. https://doi.org/10.1016/j.foreco.2011.02.030.

Tsiouvaras, C.N., N.A. Havlik, and J.W. Bartolome. 1989. Effects of goats on understory vegetation and fire hazard. For Sci 35: 1125-1131.

Underwood, E.C., J. Franklin, N.A. Molinari, and H.D. Safford. 2018. Global change and the vulnerability of chaparral ecosystems. Bull Ecol Soc Am 99: 1-10.

Wagner, V., and C.R. Nelson. 2014. Herbicides can negatively affect seed performance in native plants. Restor Ecol 22 (3): 288-291. https://doi.org/1 0.1111/rec.12089.

Westerling, A.L., and B.P. Bryant. 2008. Climate change and wildfire in California. Clim Change 87: S231-S249 https://doi.org/10.1007/s10584-007-9363-z, S1.

\section{Publisher's Note}

Springer Nature remains neutral with regard to jurisdictional claims in published maps and institutional affiliations.

\section{Submit your manuscript to a SpringerOpen ${ }^{\circ}$ journal and benefit from:}

- Convenient online submission

- Rigorous peer review

- Open access: articles freely available online

- High visibility within the field

- Retaining the copyright to your article

Submit your next manuscript at $\boldsymbol{\nabla}$ springeropen.com 